\title{
Traditional stewardship and conservation in the Game Management Areas of Nkala and Namwala, Zambia
}

\author{
Francis $\mathrm{X}$. Mranda, Austin Muakifwamba and Thakundine Simpamba
}

\begin{abstract}
We investigated the effects of socio-economic, institutional, and governance factors on two adjacent Game Management Areas in Zambia: Nkala, which is relatively pristine, and Namwala, which is degraded. Monetary benefits from the Nkala Game Management Area were almost double those from Namwala, which may have been sufficient incentive for the communities of Nkala not to occupy the area or conduct activities that were detrimental to wildlife conservation. There was no such incentive in Namwala, where traditional leaders may have considered settlement and cultivation a better alternative to wildlife conservation. The degradation of the area is largely attributable to weak governance amongst the traditional leadership, which allowed unauthorized migrants to settle and cultivate regardless of the effects of their activities. In contrast, there was good governance in Nkala, where the local chiefs did not allow settlement within the Game Management Area. We hope our findings will be useful in informing the management of Game Management Areas and other wildlife-conservation areas.
\end{abstract}

Keywords Degradation, Game Management Areas, governance, institutions, migrants, stewardship, Zambia

\section{Introduction}

Tnlike other Game Management Areas adjacent to Kafue National Park in Zambia, Nkala is undisturbed by agriculture and human settlement. In contrast, the adjacent Namwala Game Management Area has been degraded, with almost $47 \%\left(1,680\right.$ of $\left.3,600 \mathrm{~km}^{2}\right)$ extensively settled and cultivated. In 1997 Namwala was downgraded from a prime to an understocked block (Zambia Wildlife Authority, 2003; Simasiku et al., 2008), in the context of trophy hunting, which is a source of funding for management of such areas and community-development projects. An understocked block is a hunting area where species assemblages are intact but populations are scarce.

Francis X. MKanda* (Corresponding author), Austin Mwakifwamba and Twakundine Simpamba $\dagger$ Kafue National Park, Itezhi-Tezhi, Zambia E-mailmkandafrancis@yahoo.ca

*Current address: Regional Commissioner's Office, P.O. Box 3070, Moshi, Tanzania

†Current address: South Luangwa National Park, Mfuwe, Zambia

Received 29 June 2012. Revision requested 18 October 2012.

Accepted 21 March 2013. First published online 1 May 2014.
Game Management Areas of this status can sustain only minimal hunting. Nkala, however, a prime hunting block, can support optimal hunting; i.e. animals are abundant and include high-value species such as lion Panthera leo, leopard Panthera pardus, roan antelope Hippotragus equinus and sable antelope Hippotragus niger. According to the Zambia Wildlife Act of 1998 Game Management Areas were established for the sustainable utilization of wildlife through agriculture, forestry, grazing, wildlife conservation, and hunting and fisheries management. They also act as buffer zones for National Parks (Lewis et al., 1990; Lewis \& Alpert, 1997) and therefore play an ecological role in mitigating the negative effects of human activities on the Parks.

\section{Study area}

The 3,600 $\mathrm{km}^{2}$ Namwala Game Management Area lies in Itezhi-Tezhi District, in Zambia's Southern Province (Fig. 1). The soil is predominantly fertile red heavy loam and the land is mostly flat, with some steep granite hillsides. The dominant vegetation is miombo woodland, mainly comprising Julbernardia paniculata and Brachystegia spiciformis. Twenty species of large mammals occur in the area, including buffalo Syncerus caffer, elephant Loxodonta africana and hartebeest Alcelaphus lichtensteinii. All Game Management Areas are established on land under customary tenure and Namwala falls under the jurisdiction of three chiefs, Chilyabufu, Shimbizi and Kaingu (Table 1). The human population in and around Namwala is c. 20,380 (Central Statistical Office, 2011) and is predominantly Ila, although other ethnic groups are also represented (Table 1).

The $194 \mathrm{~km}^{2}$ Nkala Game Management Area is also located in Itezhi-Tezhi District (Fig. 1). Soils are predominantly Kalahari sands but there are also small, fertile alluvial plains. The landscape of Nkala is gently undulating and the central part is low lying and relatively flat, with dambos (perennially wet valleys). The three main types of vegetation are grassland, Baikiaea forest, and mixed deciduous thicket and Kalahari woodland. Twenty-five species of large mammals are known to occur, including elephant, buffalo and lion. Local communities are predominantly Ila but other ethnic groups are also present (Table 1). The human population is C. 19,500 (Central Statistical Office, 2011).

The choice of Nkala and Namwala as case studies has two advantages. Firstly, both areas are in the same district, which 


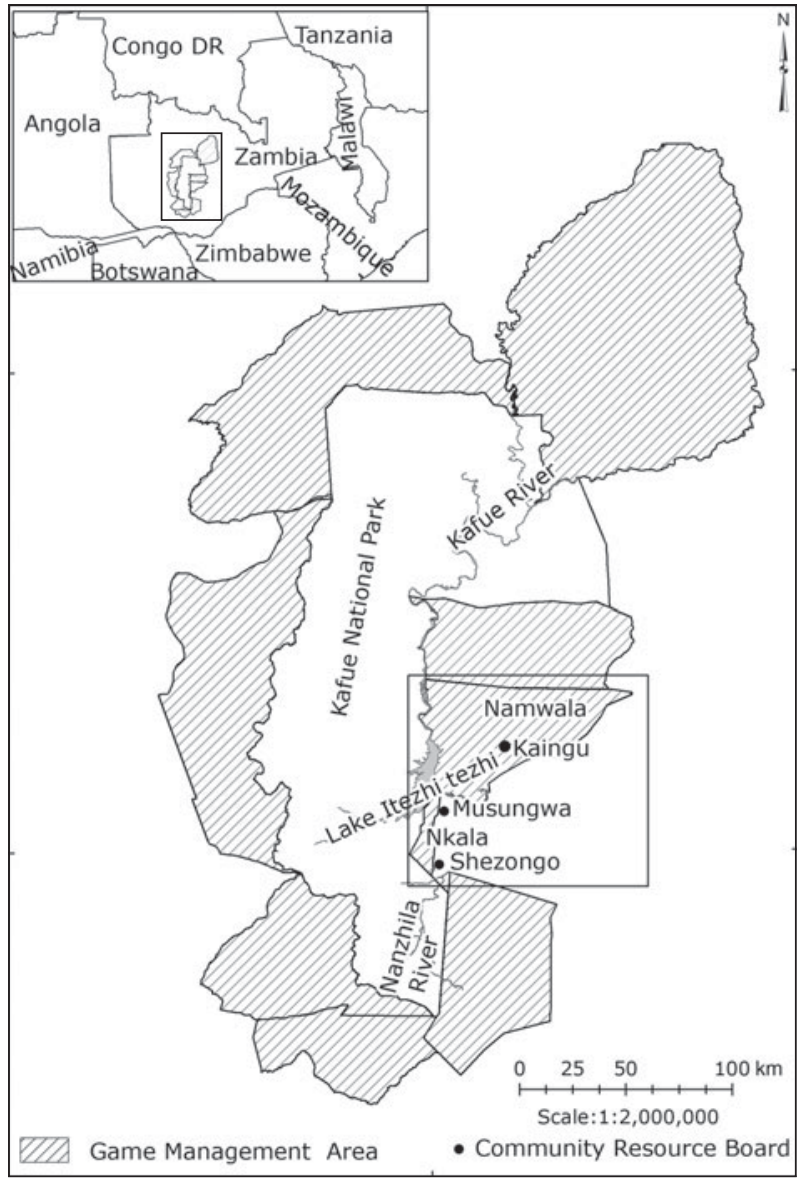

Fig. 1 Nkala and Namwala Game Management Areas. The rectangle on the inset shows the location of the main map in Zambia.

implies that they have similarities in terms of administrative and social factors. It would, therefore, be expected that any negative administrative and social factors that led to the degradation of Namwala would have had a similar effect in Nkala.

Secondly, both areas are under similar pressure from the human population. With 931,700 ha of arable land and a human population of c. 64,600 (Central Statistical Office, 2011), Itezhi-Tezhi District has an arable density of 0.07 persons $\mathrm{ha}^{-1}$. Arable density is the number of people per unit area of arable land and is a measure of selfsustainability in terms of food production (Kalipeni, 1992; Plane \& Rogerson, 1994). Given the national arable density of c. 1.9 persons ha ${ }^{-1}$, there is less pressure on land in ItezhiTezhi than in the rest of Zambia. Therefore, the extensive cultivation and settlement in Namwala is not attributable to pressure on land. It would have been preferable to compare the arable density of the two study areas on a chiefdom basis but such data are not compiled by the Central Statistical Office according to traditional authority. We could have derived the area of arable land per chiefdom from landsuitability maps but such means of data-acquisition was beyond the scope of this study.

\section{Methods}

We examined socio-economic factors, and institutional and governance aspects of the communities of Namwala and Nkala to provide an understanding of the communities' livelihoods and the choices that people make regarding the use of natural resources, to identify the types of institutions responsible for wildlife management in the Game Management Areas, and to ascertain if there was mismanagement, dysfunctionality or disproportionate capturing of benefits by individuals in positions of authority and power within communities (Aurélie et al., 2009).

\section{Questionnaire}

Parfitt (1997) recommended the use of questionnaires to gather data about people, their behaviour, attitudes and opinions, and their awareness of specific issues. We formulated a structured questionnaire comprising 82 variables in six categories: awareness and perception of benefits from the Game Management Area, knowledge of the importance of Game Management Areas, attitudes towards Game Management Areas, ownership and land-use practices, general farm characteristics, and personal background. We considered awareness and perception of the benefits as opposed to actual benefits because revenues from the Game Management Area do not accrue directly to households but to the community as a whole.

Under the Zambia Wildlife Act 1998, where a Game Management Area exists in a chiefdom, communities are required to form community resource boards to spearhead their participation in wildlife management. We used these boards as strata, two in Nkala (Musungwa and Shezongo) and three in Namwala (Shimbizhi, Kaingu and Chilyabufu), and administered 50 questionnaires in each stratum. We randomized each set of questionnaires, using a randomnumber table, following the method described by Little \& Hills (1978). Before commencing each interview we explained the overall research concept to the participant and obtained their informed consent. Interviews were conducted in the local language, Ila. Respondents' profiles gave us an insight into the composition of the communities living in or adjacent to the Game Management Areas.

We used principal factor analysis (Comrey, 1973) to identify the main socio-economic factors that contributed to the status of each Game Management Area. For Namwala we only used data from Shimbizhi and Kaingu community resource boards because several respondents from Chilyabufu appeared suspicious of the motive of the study and we considered their responses unreliable.

We subjected the variables to the correlation test, extracted and rotated the principal factors, and conducted a multiple regression analysis in JMP IN (Sall \& Lehman, 1996). We used the variables that were retained in a general 
TABLE 1 Characteristics of the ethnic groups present in Nkala and Namwala Game Management Areas, Zambia (Fig. 1).

\begin{tabular}{|c|c|}
\hline Ethnic group & Characteristics \\
\hline \multicolumn{2}{|c|}{$\begin{array}{l}\text { Nkala Game Management Area } \\
\text { (Chiefdoms: Shezongo, } 3,606 \mathrm{~km}^{2} \text {; Musungwa, } 2,676 \mathrm{~km}^{2} \text { ) }\end{array}$} \\
\hline Ila, Lumbu-Ila & Indigenous to the area; predominantly pastoralists $\&$ hunters but also engage in fishing \& have adopted agriculture \\
\hline Tonga & $\begin{array}{l}\text { Not indigenous, migrated from other chiefdoms within the Southern Province; predominantly } \\
\text { practise shifting cultivation }\end{array}$ \\
\hline \multicolumn{2}{|c|}{$\begin{array}{l}\text { Namwala Game Management Area } \\
\text { (Chiefdoms: Chilyabufu, } 1,027 \mathrm{~km}^{2} \text {; Shimbizi, } 879 \mathrm{~km}^{2} \text {; Kaingu, } 6,538 \mathrm{~km}^{2} \text { ) }\end{array}$} \\
\hline Ila & Indigenous \\
\hline Tonga & Migrants \\
\hline Lozi & $\begin{array}{l}\text { Migrants from the Western Province; practise pastoralism \& some agriculture but predominantly fishing } \\
\text { in Namwala }\end{array}$ \\
\hline Bemba & Migrants from Luapula Province, predominantly fishers \\
\hline Luvale & Migrants from the North Western Province; hunters \& fishers \\
\hline Mbunda & Migrants from the Western Province; fishers \\
\hline
\end{tabular}

TABLE 2 Profile of questionnaire respondents in Namwala and Nkala Game Management Areas (Fig. 1).

\begin{tabular}{|c|c|c|}
\hline \multirow[b]{2}{*}{ Variable } & \multicolumn{2}{|c|}{ No. of respondents } \\
\hline & Namwala & Nkala \\
\hline \multicolumn{3}{|l|}{ Age (years) } \\
\hline$<20$ & 0 & 2 \\
\hline $21-40$ & 71 & 38 \\
\hline$>40$ & 27 & 46 \\
\hline \multicolumn{3}{|l|}{ Level of education } \\
\hline None & 5 & 1 \\
\hline Primary & 64 & 53 \\
\hline Secondary & 29 & 34 \\
\hline Tertiary & 2 & 12 \\
\hline \multicolumn{3}{|c|}{ Profit from farm income (ZMK 1,000$)$} \\
\hline 0 & 81 & 47 \\
\hline$<1,000-10,000$ & 9 & 38 \\
\hline$>10,000$ & 1 & 0 \\
\hline \multicolumn{3}{|c|}{ Profit from non-farm income (ZMK 1,000$)$} \\
\hline 0 & 0 & 5 \\
\hline$<1,000-10,000$ & 1 & 19 \\
\hline$>10,000$ & 0 & 3 \\
\hline \multicolumn{3}{|c|}{ Other work undertaken } \\
\hline Unskilled labour & 17 & 10 \\
\hline Fishing & 22 & 6 \\
\hline Micro enterprises & 4 & 2 \\
\hline Professional & 0 & 4 \\
\hline Skilled labour & 9 & 14 \\
\hline
\end{tabular}

multiple linear regression model to identify those that contributed to the status of each Game Management Area. Following Brierley (1978), we ignored any variable that did not contribute significantly to the multiple regression model $(\mathrm{P}>0.05)$. Eventually we retained only variables that were specific to each Game Management Area as the principal factors. We used a $\chi^{2}$ test to determine if any observed differences in the principal factors for each Game Management Area were statistically significant.

\section{Assessment of benefits}

We categorized benefits as monetary and non-monetary. We examined the former in terms of revenue flows from trophy hunting (animal sales, licences, and concession fees) for 2005-2010 because these data were readily available. Our calculations of the revenue from Namwala did not include hunting concession fees because under the Hunting Concession Agreement hunting outfitters are exempt from such fees in an understocked Game Management Area. For both Namwala and Nkala we excluded revenue from tourism because lodge operators are not compelled to share their earnings with communities.

We analysed revenue based on the mutually agreed allocations between Zambia Wildlife Authority and the communities. There are two categories of revenue from trophy hunting: animal sales and licences, and concession fees. Revenue from animal sales and licence fees is shared equally between Zambia Wildlife Authority and community resource boards. Of the $50 \%$ allocated to communities $5 \%$ goes to the chiefs (as patrons) and $45 \%$ is used for administration, resource protection and communitydevelopment projects. Eighty percent of the concession fee goes to Zambia Wildlife Authority and $20 \%$ goes to the communities ( $15 \%$ for projects and $5 \%$ for the patrons). For comparison between Nkala and Namwala we considered the total revenue allocated to the communities in terms of income per household, although monetary benefits are not disbursed directly to families. We categorized all nonmonetary benefits as food, building materials and other. Within each category we calculated and compared the number of responses for the two Game Management Areas.

\section{Institutions and governance}

We examined aspects of institutions and governance for the pre-colonial and post-independence periods. Zambia was 
TABLE 3 Retained variables and their $\chi^{2}$ values in principal factor analysis of the status of Namwala and Nkala Game Management Areas (Fig. 1).

\begin{tabular}{lll}
\hline Category & Variable & $\chi^{2}$ \\
\hline $\begin{array}{l}\text { Namwala } \\
\text { Ownership \& land-use practices }\end{array}$ & $\begin{array}{l}\text { Do not own land } \\
\text { Fertilizer application }\end{array}$ & 0.05 \\
& Soil erosion is a problem & $<.001$ \\
General farm characteristics & Land held communally & $<.0001$ \\
Nkala & & $<0.0001$ \\
Awareness \& perception of benefits & Benefits from Game Management Areas satisfactory & $<0.0001$ \\
& Awareness of the source of funds for community resource board projects & 0.0003 \\
Attitude towards Game Management Areas & Awareness of projects that the community resource boards are undertaking & 0.0019 \\
Respondent's background & Presence and support when the Game Management Area was established & $<0.0001$
\end{tabular}

colonized by the British towards the end of the 19th century and gained independence in December 1963, with the dissolution of the Federation of Northern and Southern Rhodesia (now Zambia and Zimbabwe, respectively) and Nyasaland (now Malawi). Institutional aspects were examined for both periods but governance aspects were considered only post-independence, having become an issue of concern in the past decade. During the colonial period management of wildlife was predominantly the preserve of the colonial administration.

We reviewed literature that described the types of institutions, both traditional and modern, that are responsible for the management of the Game Management Areas, including constitutions of the community resource boards, and guidelines for selection of board members. We also scrutinized financial records of community resource boards to determine their integrity in managing funds on behalf of communities. We assumed that there was collaboration rather than competition between the chiefs because they were instrumental in the formulation of management plans for the Game Management Areas. Three chiefs took joint legal action against unauthorized migrants in the Namwala Game Management Area, which is further evidence of interest and collaboration.

\section{Results}

\section{Profile of respondents}

The human population in both study areas is predominantly young and educated to primary level at least (Table 2). In terms of income, there are similarities in the profiles of the respondents from the two Game Management Areas, but respondents from Nkala had higher income from non-farming micro-enterprises whereas respondents from Namwala had higher income from other types of work (Table 2). The majority of respondents had incomes below
TABLE 4 Income per household from trophy hunting in Namwala and Nkala Game Management Areas (Fig. 1) during 2005-2010.

\begin{tabular}{lcrr}
\hline & \multicolumn{2}{l}{ Income per household $\left(\mathrm{ZMK}^{\star}\right)$} & \\
\cline { 2 - 3 } Year & Nkala & Namwala & Difference \\
\hline 2005 & $51,328.86$ & $23,622.45$ & $27,706.41$ \\
2006 & $26,335.57$ & $1,581.63$ & $24,753.94$ \\
2007 & $49,234.90$ & $17,423.47$ & $31,811.43$ \\
2008 & $72,080.54$ & $27,066.33$ & $45,014.21$ \\
2009 & $66,067.11$ & $24,897.96$ & $41,169.15$ \\
2010 & $57,342.28$ & $29,974.49$ & $27,367.79$ \\
Total & $322,389.30$ & $124,566.30$ & $197,823.00$ \\
\hline
\end{tabular}

${ }^{*}$ ZMK 4,700 was equivalent to USD 1 in August 2011.

the mean per capita income of ZMK 1.2 million for the rural community in Zambia (Central Statistical Office, 2004). Given the similarities between the community profiles for Namwala and Nkala we ruled this out as a cause of difference in the status of the two Game Management Areas.

\section{Socio-economic factors}

The socio-economic factors influencing the status of Namwala relate to land use and ownership, although the tenure system is the same in both protected areas, whereas in Nkala they mostly relate to awareness, attitude and background (Table 3). Respondents from Nkala claimed that they had supported the establishment of the Game Management Area. The $\chi^{2}$ test revealed that all retained variables were significantly associated with a particular Game Management Area (Table 3).

\section{Benefits}

Respondents from Nkala received almost twice as much revenue from trophy hunting as those from Namwala (Table 4). This is not surprising because being an 
TABLE 5 Non-monetary benefits from Nkala and Namwala Game Management Areas (Fig. 1).

\begin{tabular}{lrrr}
\hline & \multicolumn{2}{l}{ No. of responses } & \\
\cline { 2 - 3 } Benefits & Namwala & Nkala & Total \\
\hline Food & 2 & 18 & 20 \\
$\quad$ Fish & 12 & 11 & 23 \\
$\quad$ Honey & 4 & 3 & 7 \\
$\quad$ Mushroom & 0 & 11 & 11 \\
$\quad$ Meat & & & \\
Building materials & 4 & 19 & 23 \\
$\quad$ Grass & 18 & 13 & 31 \\
$\quad$ Poles & & & \\
Other & 0 & 16 & 16 \\
$\quad$ Environmental education & 0 & 24 & 24 \\
$\quad$ Employment & 0 & 8 & 8 \\
$\quad$ Firewood & 3 & 11 & 14 \\
$\quad$ Medicine & 0 & 35 & 35 \\
$\quad$ Pasture & 1 & 2 & 3 \\
$\quad$ Recreation & 2 & 7 & 9 \\
$\quad$ Water & 33 & 18 & 51 \\
None & & &
\end{tabular}

understocked Game Management Area, Namwala did not receive concession fees, which can account for as much as $60 \%$ of the total income from trophy hunting. The annual variation in this percentage depends on revenue from animal sales; concession and licence fees are fixed. With respect to non-monetary benefits there were more responses from Nkala than Namwala, and the latter reported fewer benefits (Table 5).

\section{Institutions}

During the pre-colonial period totemism and traditional institutions were instrumental in the conservation of wildlife. The Ila of Shimbizhi, Chilyabufu and Musungwa chiefdoms (Fig. 1; Table 1) and the Lumbu-Ila of Shezongo were totemic (Jaspan, 1953); they named most of their clans after wildlife species and certain plants and they never utilized those species. Like many African tribes the Ila and Lumbu-Ila were organized around a system of clanship and chiefdom. Each chiefdom had laws, traditions, beliefs, customs and values that governed the conservation of wildlife. A small group of matrilineal kinsmen within one commune (cishi) acted as a unit to prosecute offenders involved in unlawful harvesting of animals or trees, or other offences (Jaspan, 1953). Hunting usually occurred annually for ceremonies or general consumption and was conducted in accordance with chiila, a traditional way of setting a quota and deciding how the meat should be distributed among clans in a particular area (Jaspan, 1953). Such traditional institutions, therefore, regulated the use of natural resources, including wildlife. Although they also had traditional institutions, the Nkoya-speaking people of the Kaingu, Shimbizhi, and Chilyabufu chiefdoms in Namwala were never totemic and were more inclined to harvest natural resources by means of traditional hunting than to foster the spirit of conservation. After independence, the idea of community-based natural resources management came into being in Zambia. It began with the formation of the Administrative Management and Design of Game Management Areas programme, which was based on a revenue-sharing scheme between communities living in Game Management Areas and the Department of National Parks and Wildlife Service, which later became the Zambia Wildlife Authority (Lewis et al., 1990). The programme was initiated in the mid 1980s, with support from the United States Agency for International Development. Besides revenue-sharing the concept of village scouts was introduced, whereby communities employ local residents in wildlife protection and management activities. Professional hunters are also involved in this collaboration between communities and the Zambia Wildlife Authority, and are the main source of funds for the former and the latter. The Zambia Wildlife Act provides the legal basis for the co-management of wildlife in Game Management Areas.

\section{Governance}

Members of a community resource board are democratically elected. Traditional leaders and other local authorities are represented and the local chief plays the role of patron. Criteria for the election of office bearers are outlined in the board's constitution and include citizenship, residence in the area, and ability to read and write English. Further guidance on the selection of members is provided in Part III of the Zambia Wildlife Act. Community resource boards are accountable to communities and regular meetings ensure that communities are kept informed of key decisions. The Zambia Wildlife Authority conducts financial audits of community resource boards and we were not aware of any financial anomalies in any boards in the area at the time of the study. There were no known cases of any form of mismanagement or disproportionate accrual of benefits by the people entrusted with funds for the community. The only exception was weak governance by some traditional leaders in Namwala.

Since the late 1990s there had been an unregulated influx of migrants to Namwala, mostly Tonga from other chiefdoms in the province as a result of the failure of certain head persons to follow traditional procedures for allocating land. Chiefs assign land for various uses through village head persons, who cannot allocate land without the chief's consent. If individuals wish to move from one chiefdom to another they are expected to follow traditional procedures. 
Firstly, they must approach the head person in whose area they wish to settle. Secondly, they need to get the consent of the chief prior to settling on the new land. Lastly, they have to obtain transfer letters from the chief of the chiefdom from which they intend to move.

Initially the in-migration was properly controlled by adherence to traditional procedure and posed no threat to the Game Management Area. Informal zoning took place and cultivation and settlement were prohibited in areas designated for conservation. In the late 1990 os and early 2000s, however, the in-migration got out of control. Migrants moved into what they saw as vacant land and established large farms in the areas that had been set aside for conservation. They practised traditional cultivation methods such as shifting cultivation. Charcoal production increased, making Namwala one of the three highest charcoal-producing Game Management Areas nationally (Simasiku et al., 2008). Resources such as honey declined, as did trophy hunting because the wildlife dwindled. Local people complained to their chiefs about the destruction of habitat by the migrants, which was in contravention of the draft management plan that had been adopted by the communities, community resource boards and other stakeholders (the Zambia Wildlife Authority, lodge operators, the district council and various government departments) as part of a project by the Danish Development Agency. They demanded that the chiefs enforce the plan and the chiefs agreed to do so.

In 2009 attempts were made to remove unauthorized migrants and a court ordered that the issue be resolved amicably and that the chiefs should provide alternative land, which they did. However, the migrants objected to moving and took a court injunction against any attempt to move them out of the Game Management Area. The chiefs won their case and it was ruled that the settlers be forcibly removed. The migrants were moved out of the Game Management Area in 2010. The eviction affected 144 households, comprising 1,252 individuals or $6 \%$ of the entire population of the Namwala Game Management Area.

\section{Discussion}

Studies have found that young people in Africa have a positive attitude towards conservation and that people with some formal education tend to be aware of and have a positive attitude towards wildlife management (Infield, 1988; Shibia, 2010). However, our results indicate that the respondents from Namwala were unaware of the importance of conservation, which may indicate that they were detached from the Game Management Area. Such detachment could be a result of weak inter-linkage between benefits, attitudes and awareness and support for conservation in Namwala (Infield, 1988).
An anonymous reviewer of this study criticized the revenue-sharing mechanism that exists between the Zambia Wildlife Authority and local communities, alleging that it favours the former and helps to explain why Namwala has become understocked, with negative financial consequences (Table 4). The reviewer maintained that if all revenues were returned to local communities there would be a greater incentive to conserve wildlife. We argue that if the revenuesharing mechanism were a problem, it would have affected Nkala equally.

In-migration, sanctioned by chiefs to claim authority over land that was lost when the Game Management Areas were established (Simasiku et al., 2008), is another possible reason for respondents' detachment. Migrants are less likely to have emotional ties with the land because they are not the de facto owners, and therefore they cannot be expected to be committed to conservation of the soil and other natural resources. When soil conservation is neglected, the cultivated land becomes degraded, farmers are forced to open up new land to cultivate, thereby reducing the habitat available for wildlife. Other studies have also related lack of land ownership and in-migration to soil degradation and negative environmental effects (Lee, 1980; Child, 1996).

The people of Nkala once resided in the area that is now Kafue National Park. When the Park was established in 1950 they were relocated but the Ila and Lumbu-Ila from Shezongo chiefdom retained their usufruct rights to the Park, where they fish in the Nanzhila River, and therefore they retained some sense of traditional ownership of the land. This sense of ownership may explain why they have maintained the Game Management Area, which was established on land excised from the Park, in a relatively pristine state. This is not the case with Namwala, where only the Nkoya-speaking people of Kaingu lived in the Park prior to their relocation to Itumbi and Kanzwa, which are within the Game Management Area. Therefore, they are more likely to have emotional ties with the land in the Park rather than the Game Management Area. The Ila of Shimbizhi and Chilyabufu have always resided outside the protected area (Fig. 1) and therefore are also less connected with it.

The presence of people from Shezongo and Musungwa chiefdoms and their support for establishment of the Nkala Game Management Area (Table 3) may also explain the positive attitude of the people of Nkala towards the protected area. Under good governance, they have restrained themselves and others from settling in the Game Management Area. Salafsky et al. (2001) noted that a community of stakeholders will act to counter a threat to a resource if biodiversity conservation generates benefits. Another reviewer of this article argued that soil fertility may have been the motivation for the migration, the soil in Namwala being more suitable for cultivation than that in Nkala. However, if soil fertility was the determinant, the migrants could have settled in any other fertile area in 
the Southern Province (Bbilili or Sichifulo Game Management Areas). Therefore we rule out soil fertility as the sole determinant for the migration.

From historical and cultural perspectives there is no doubt that traditional beliefs and institutions ensured that wildlife was conserved and reinforced the value of communal ownership of wildlife resources amongst the Ila and Lumbu-Ila. Although not widely practised now, such traditional practices are still deep-rooted and therefore it is not surprising that the Lumbu-Ila and Ila of Shezongo and Musungwa and the Ila of Shimbizi and Chilyabufu chiefdoms chose not to occupy the Game Management Areas (Fig. 1), unlike the Nkoya-speaking people of the Namwala Game Management Area. This demonstrates the importance of the background of respondents as one of the factors retained during the analysis of socio-economic variables.

It is also evident that although the institutions seem to be strong in both Nkala and Namwala Game Management Areas, poor governance appears to have been the key cause of degradation in Namwala. We did not find any financial anomalies in the management of Namwala Game Management Area, and therefore we rule out lack of integrity of the community resource board, which advocated the implementation of a management plan that had been approved by communities and other stakeholders (but not yet by the Zambia Wildlife Authority). Some conservationists are critical of the applicability of management or land-use plans for the Game Management Areas. They argue that formulation of such plans is merely an academic exercise; the products are simply bookshelf documents (H.K. Mwima, pers. comm.). The case of Namwala has proved such critics right; the management plan was not implemented effectively, hence the degradation of this area.

Nkala and Namwala Game Management Areas exemplify stewardship by community resource boards and chiefs, albeit in different ways. The chiefs in Nkala refused to allow migrants to settle within the Game Management Area. In Namwala the chiefs acted to rectify mistakes arising from weak governance, showing that a strong community institution can force improvements in traditional leadership. It is encouraging to observe such stewardship when others have expressed scepticism about the role of communities in natural resources management. Musumali et al. (2007), for example, observed a general incongruence between community perceptions and expectations regarding stewardship of community-based natural resources management in Luangwa, Zambia, and Chobe, Botswana.

At the time of this study, management plans for the two Game Management Areas had been approved by the Zambia Wildlife Authority for implementation, which will be facilitated by the stewardship of the chiefs and community resource boards. We hope that when these plans are being revised all stakeholders will consider the lessons learned from the experience of dealing with in-migration. These lessons and experiences could be incorporated into new management plans for other Game Management Areas in Zambia.

\section{Acknowledgements}

We thank Melody Zeko and Lucy Tembo for reviewing the questionnaire, Likukela Simasiku and Maswau Sililo for providing data on management plans and revenue from trophy hunting, Anety Milimo for preparing the map and entering data, and the respondents to our questionnaire, who provided important socio-economic data. The Kafue Programme, funded by the World Bank, and the Norwegian Government supported the study financially.

\section{References}

Aurélie, B., Blomley, T., Coad, L., Nelson, F., Roe, D. \& SANDBRook, C. (2009) What has CBNRM achieved in Africa? The 3Es-empowerment, economics, environment. In Community Management of Natural Resources in Africa: Impacts, Experiences and Future Directions (eds D. Roe, F. Nelson \& C. Sandbrook), pp. 55-81. IIED, London, UK.

Brierley, J.S. (1978) Analysis of population change in the Canadian prairies, 1971-76. Great Plains-Rocky Mountain Geographical Journal, 7, 1-8.

Central Statistical Office (2004) Living Conditions Monitoring Survey Report. Central Statistical Office, Lusaka, Zambia.

Central Statistical Office (2011) Census of Population and Housing. Central Statistical Office, Lusaka, Zambia.

Child, B. (1996) The practice and principles of community-based wildlife management in Zimbabwe: the CAMPFIRE programme. Biodiversity and Conservation, 5, 369-398.

Comrey, A. (1973) First Course in Factor Analysis. Academic Press, New York, USA

InfIELD, M. (1988) Attitudes of a rural community towards conservation and a local conservation area in Natal, South Africa. Biological Conservation, 45, 21-46.

Jaspan, M. (1953) The Tonga-Ila Speaking People of Northern Rhodesia: Surveys for the Royal Anthropological Institute. Macmillan Publishers, London, UK.

Kalipeni, E. (1992) Population growth and environmental degradation in Malawi. Africa Insight, 22, 273-282.

LEE, L.K. (1980) The impact of land ownership factors on soil conservation. American Journal of Agricultural Economics, 62, 1071-1076.

Lewis, D. \& Alpert, P. (1997) Trophy hunting and wildlife conservation in Zambia. Conservation Biology, 11, 59-68.

Lewis, D., Kaweche, G.B. \& Mwenya, A. (1990) Wildlife conservation outside protected areas-lessons from an experiment in Zambia. Conservation Biology, 4, 171-180.

Little, T.M. \& Hills, F.J. (1978) Agricultural Experimentation: Design and Analysis. John Wiley \& Sons, New York, USA.

Musumali, M.M., Larsen, T.S. \& Kaltenborn, B.J. (2007) An impasse in community-based natural resource management implementation: the case of Zambia and Botswana. Oryx, 41, 306-313. 
PArfit T, J. (1997) Questionnaire design. In Methods in Human Geography: a Guide for Students Doing a Research Project (eds E. Flowerdew \& D. Martin), pp. 77-109. Longman, London, UK.

Plane, D.A. \& Rogerson, P.A. (1994) The Geographical Analysis of Populations: With Applications to Planning and Business. John Wiley \& Sons, New York, USA.

Salafsky, N., Cauley, H., Balachander, G., Cordes, B., Parks, J., MARGoluis, C. et al. (2001) A systematic test of an enterprise strategy for community-based biodiversity conservation. Conservation Biology, 15, 1585-1595.

SALL, J. \& Lehman, A. (1996) JMP Start Statistics: A Guide to Statistics and Data Analysis Using JMP and JMP IN Software. Thomson, New York, USA.

Shibia, M.G. (2010) Determinants of attitudes and resource use and management of Marsabit National Reserve, Kenya. Journal of Human Ecology, 30, 55-62.

Simasiku, P., Simwanza, H.I., Tembo, G., Bandyopadhyay, S. \& PAVy, J-M. (2008) The Impact of Wildlife Management Policies on
Communities and Conservation in Game Management Areas in Zambia: Message to Policy Makers. National Resources Consultative Forum, Lusaka, Zambia.

Zambia Wildlife Authority (2003) Safari Hunting Monitoring Manual. Zambia Wildlife Authority, Chilanga, Zambia.

\section{Biographical sketches}

FRANCIS MKANDA is a wildlife-management specialist and has worked on wildlife conservation in Southern Africa for over 2 decades. His research interests include ecology and socio-economics. Austin MWAKIFWAMBA is a protected-area socio-economist with experience in community-based natural resources management in Zambia. His research interests include socio-economics and the human-wildlife interface. TWAKUNDINE SIMPAMBA is a wildlife ecologist working in protected areas in Zambia. His areas of interest are the effects of fire and herbivores on vegetation, sustainable harvesting and its effect on trophy quality, and wildlife population studies. 